\title{
Astaxanthin Formation by the Yeast Phaffia rhodozyma
}

\author{
By ERIC A. JOHNSON* AND MICHAEL J. LEWIS $\dagger$ \\ Department of Food Science and Technology, University of California, Davis, California \\ 95616, U.S.A.
}

(Received 5 January 1979)

\begin{abstract}
The production of carotenoid pigments by the yeast Phaffia rhodozyma depended on the culture conditions. Astaxanthin, the primary carotenoid in this yeast, was produced mainly during the exponential phase of growth. The concentration of carotenes in $P$. rhodozyma remained relatively constant [about $5 \mu \mathrm{g}$ (g yeast) ${ }^{-1}$ ] throughout growth in a $1.5 \%(\mathrm{w} / \mathrm{v})$ glucose medium, but the xanthophyll concentration increased from 90 to $406 \mu \mathrm{g}$ (g yeast) ${ }^{-1}$ during fermentation. Active xanthophyll synthesis occurred during the period of accelerating growth and after exhaustion of glucose from the growth medium. In media containing more than $1.5 \%(\mathrm{w} / \mathrm{v})$ glucose, however, yeast and carotenoid yields were considerably reduced. The $\mathrm{pH}$ of the medium affected yeast yields and carotenoid production; the optimum $\mathrm{pH}$ was $5 \cdot 0$. At pH 3.5, $\beta$-zeacarotene accumulated in $P$. rhodozyma. $\beta$-Carotene was the primary carotene in the yeast under all other conditions tested. The optimum temperature for yeast growth and pigment formation was 20 to $22{ }^{\circ} \mathrm{C}$ and the best carbon source was D-cellobiose. Oxygen was an important substrate for optimum yields of yeast and astaxanthin; under microaerophilic growth conditions, astaxanthin production was drastically decreased and $P$. rhodozyma accumulated $\beta$-carotene and the monoketone echinenone.
\end{abstract}

\section{INTRODUCTION}

The red yeasts of the genera Cryptococcus, Rhodotorula, Rhodosporidium, Sporidiobolus and Sporobolomyces are very similar in their carotenoid composition. They contain $\beta$-carotene $\left(\beta, \beta\right.$-carotene), $\gamma$-carotene $(\beta, \gamma$-carotene $)$, torulene $\left(3^{\prime}, 4^{\prime}\right.$-didehydro- $\beta, \Psi^{\prime}$-carotene $)$ and torularhodin $\left(3^{\prime}, 4^{\prime}\right.$-didehydro- $\beta, \Psi^{\prime}$-carotene-16'-oic acid) as their major pigments (Simpson et al., 1971). Recently, plectaniaxanthin $\left(3^{\prime}, 4^{\prime}\right.$-didehydro-1', $2^{\prime}$-dihydro- $\beta, \Psi$ carotene-1', $2^{\prime}$-diol) has been found in Cryptococcus laurentii (Bae et al., 1971) and 2-hydroxyplectaniaxanthin in Rhodotorula aurantiaca (Liu et al., 1973) which has added some structural diversity to the carotenoids found in this group of fungi. Phaffia rhodozyma is a recently discovered yeast (Miller et al., 1976) that is strikingly different from the other pigmented yeasts in producing the carotenoid pigment astaxanthin $\left(3,3^{\prime}\right.$-dihydroxy- $\beta, \beta-$ carotene-4,4'-dione) (Andrewes et al., 1976).

Though astaxanthin is rarely found in the fungi [it has occasionally been isolated from the basidiomycetes Peniophora auranthica and Pe. quercina of the Aphyllophorales (Goodwin, 1972)], it is common in the animal kingdom. It is conspicuously displayed in the plumage of many birds including flamingoes and the scarlet ibis, in marine invertebrates such as lobsters, crabs and shrimps, and in fishes such as trout and salmon, where astaxanthin is responsible for flesh colour. These fish, when raised in pens, often lack desirable red flesh colour. In an earlier study (Johnson et al., 1977) we found that a preparation of $P$.rhodozyma is a potentially important source of astaxanthin for pen-reared salmonjds, as the yeast pigment is rapidly accumulated from the feed and deposited in the flesh of rainbow trout.

* Present address: Department of Nutrition \& Food Science, Massachusetts Institute of Technology Cambridge, Massachusetts 01239, U.S.A.

$\dagger$ To whom requests for reprints should be sent. 
Though some metabolic characteristics of this yeast have been reported (Phaff et al., 1972; Miller et al., 1976), these were not studied in relation to astaxanthin formation. The purpose of this study was to investigate the effect of culture conditions on astaxanthin formation in $P$. rhodozyma with a view to optimizing pigment production.

\section{METHODS}

Yeast and culture conditions. The type strain of Phaffia rhodozyma (UCD 67-210) was obtained from the yeast culture collection of this department. The yeast was maintained on slants of yeast extract/malt extract agar (YM agar, Difco) at $4{ }^{\circ} \mathrm{C}$.

Flask cultures were grown on an orbital shaker (Environ-Shaker 3597, Lab Line Instruments) at $22{ }^{\circ} \mathrm{C}$ in $500 \mathrm{ml}$ baffled side-arm flasks. All shake flask experiments were performed in triplicate. Yeast extract/malt extract broth (YM broth) supplemented with antifoam (FG-10, Dow Corning) at $0 \cdot 1 \mathrm{ml} \mathrm{l}^{-1}$ was the usual growth medium. A medium of yeast nitrogen base (YNB) broth lacking amino acids and ammonium sulphate (Difco) was used in carbon and nitrogen assimilation experiments; carbon and nitrogen sources were added as required. Shake flasks contained $50 \mathrm{ml}$ medium unless otherwise stated. Media were buffered at $\mathrm{pH} 5 \cdot 0$ with $0 \cdot 1 \mathrm{M}$-potassium hydrogen phthalate buffer.

Fermenter cultures were grown in a Virtis 201 fermenter (model 43-100, Virtis Co., Gardener, N.Y., U.S.A.) at $20^{\circ} \mathrm{C}$ using a 141 working volume, an air flow rate of $81 \mathrm{~min}^{-1}$ and a stirring rate of 400 rev. $\mathrm{min}^{-1}$. The standard medium contained (per litre): Cerelose (CPC International, Englewood Cliffs, N.J., U.S.A.) $20 \mathrm{~g} ;\left(\mathrm{NH}_{4}\right)_{2} \mathrm{SO}_{4}, 2 \mathrm{~g} ; \mathrm{KH}_{2} \mathrm{PO}_{4}, 1 \mathrm{~g} ; \mathrm{MgSO}_{4} .7 \mathrm{H}_{2} \mathrm{O}, 0.5 \mathrm{~g} ; \mathrm{CaCl}_{2} .2 \mathrm{H}_{2} \mathrm{O}, 0.1 \mathrm{~g}$; yeast extract (Difco), $2 \mathrm{~g}$; antifoam, $0.1 \mathrm{ml}$. $\mathrm{pH}$ was monitored with a sterilizable $\mathrm{pH}$ probe and controlled at $\mathrm{pH} 4.8$ by automatic titration with $4 \mathrm{M}-\mathrm{KOH}$.

Shake flasks were inoculated with $1 \%(\mathrm{v} / \mathrm{v})$ and fermenters with $2 \%(\mathrm{v} / \mathrm{v})$ of a $20 \mathrm{~h}$ washed cell suspension containing about $1.5 \mathrm{mg}$ yeast dry wt ml-1 ${ }^{-1}$. An additional volume $(0.02 \%, \mathrm{v} / \mathrm{v})$ of sterile antifoam was added near the middle of the exponential phase of growth to prevent foaming. Yeast growth rate is expressed as the specific growth rate $\mu\left(\mathrm{h}^{-1}\right)$, and in flask culture was estimated during the exponential phase of growth by measuring the increase in absorbance of the culture broth at $600 \mathrm{~nm}$ in a Klett photometer (Arthur H. Thomas Co., Philadelphia, Pa., U.S.A.). Growth rate in the fermenter was estimated by measuring the increase in cell dry weight as described by Johnson et al. (1978). Cultures were harvested by centrifuging after reaching a constant absorbance or dry weight, washed with water, and frozen at $-20^{\circ} \mathrm{C}$ to await analysis. The yeast yield $(Y)$ is defined as $Y=X_{\mathrm{f}}-X_{0}$, where $X_{\mathrm{f}}$ and $X_{0}$ are the final and initial yeast dry weights $\left(\mathrm{mg} \mathrm{ml}^{-1}\right)$, respectively.

For light induction experiments, $P$. rhodozyma was grown in an orbital shaker incubator equipped with two fluorescent tube lamps which provided $2700 \mathrm{~lx}$ at the culture surface. Control flasks were covered with aluminium foil.

Analyses of culture media. Reducing sugar concentration $\left(\mathrm{mg} \mathrm{ml}^{-1}\right)$ in the culture medium was determined with the 3,5-dinitrosalicylic acid reagent (Sumner \& Somers, 1949). The rate of dissolution of oxygen into culture media was estimated by the sulphite oxidation method (Cooper et al., 1944). The results are expressed as $\mathrm{mmol} \mathrm{O}_{2}$ dissolved $\mathrm{l}^{-1} \mathrm{~h}^{-1}$.

Carotenoid extraction and analysis. For routine analyses of astaxanthin, $P$. rhodozyma cell suspensions were mixed with $0.5 \mathrm{~mm}$ glass beads, and then vibrated for $3 \mathrm{~min}$ in a Braun homogenizer (Bronwill Scientific, Rochester, N.Y., U.S.A.). The broken cells were thoroughly stirred in about 20 vol. acetone, centrifuged, and the pigments in the supernatant were transferred to petroleum ether with the addition of dilute $\mathrm{NaCl}$ solution. Astaxanthin concentration in the petroleum ether extract was estimated by measuring the absorbance at $\lambda_{\max }\left(474 \mathrm{~nm}\right.$ ). The specific absorption coefficient $A_{\mathrm{lcm}}^{1 \%}=1600$ (Andrewes et al., 1976) and the formula provided by Davies (1976) allowed the calculation of astaxanthin concentration.

Petroleum ether extracts of carotenoid mixtures to be chromatographed were dried over $\mathrm{Na}_{2} \mathrm{SO}_{4}$ and concentrated by rotary evaporation at $3 \mathrm{C}^{\circ} \mathrm{C}$ in subdued light. The carotenes were separated from the xanthophylls on a MN Kieselgel (Brinkmann Instruments) column by elution with 3\% (v/v) diethyl ether in petroleum ether. Xanthophylls were eluted with acetone. The total concentration of xanthophylls and carotenes in the eluates was estimated by measuring $A_{478}$ for xanthophylls and $A_{448}$ for the carotenes (but $A_{428}$ in cells grown at pH 3.5, see text) using the absorption coefficients $A_{1 \mathrm{com}}^{1 \%}=1600$ and 2600 , respectively. The individual eluates were sometimes further chromatographed by thin-layer chromatography on aluminium oxide (Alox $25 \mathrm{UV}_{254}$; Brinkmann Instruments) and silica gel (Silica Gel 60; EM Laboratories) using various combinations of acetone, ethyl ether and petroleum ether as developing solvent mixtures.

Identification of carotenoids. Carotenoids which had been purified to chromatographic homogeneity were characterized by their electronic absorption spectrum, by co-chromatography with identical or related pure carotenoids in two solvent systems and by their mass spectrum (if sufficient material was available). 


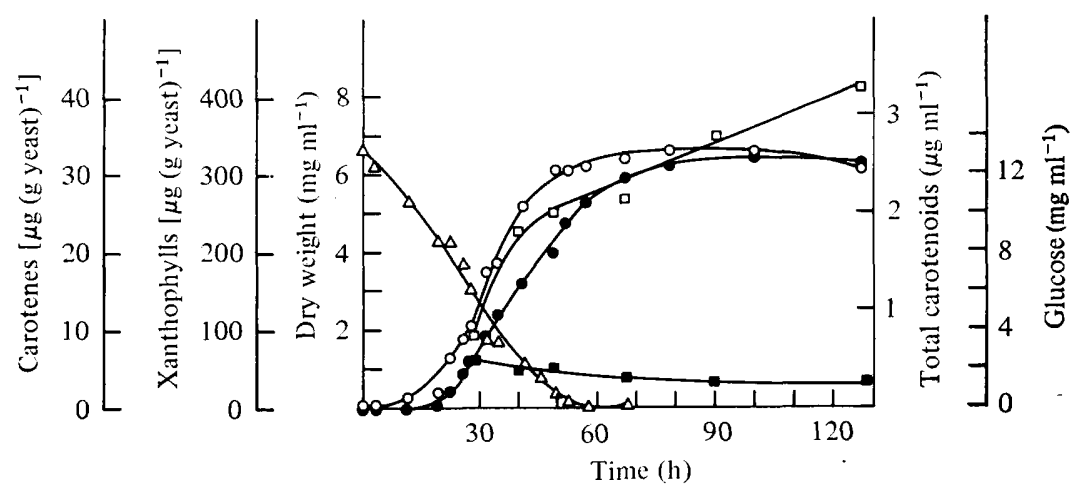

Fig. 1. Production of carotenoids by $P$. rhodozyma in fermenter batch culture. Yeast growth $(O)$, total carotenoid formation (O), xanthophyll (astaxanthin) formation ( $\square$ ), carotene synthesis ( $\square$ ) and glucose utilization $(\triangle)$. The growth medium initially contained $1.5 \%(w / v) D$ glucose.

Visible absorption spectra were recorded in acetone, and concentrations of carotenoids were calculated using the specific absorption coefficients provided by Davies (1976). The mass spectra were determined on a Finnegan 3200 instrument at $220^{\circ} \mathrm{C}$ with an ionization voltage of $70 \mathrm{eV}$.

Chemicals. All chemicals were, where possible, of analytical grade. D-Mannitol, $\mathrm{L}$-arabinose and D-xylose were obtained from ICN Pharmaceuticals, Cleveland, Ohio, U.S.A.; cellobiose was from Sigma, glucono$\delta$-lactone from Merck; maltose from Calbiochem; sucrose, succinic acid, D-glucose, potassium hydrogen phthalate, phosphate salts and all solvents from Mallinckrodt, St. Louis, Mo., U.S.A.; and 3,5-dinitrosalicylic acid from Eastman Kodak Co.

\section{RESULTS}

\section{Growth and astaxanthin production}

In fermenter batch culture, growth of $P$. rhodozyma began after a $10 \mathrm{~h} \mathrm{lag}$ and a constant dry weight of yeast was reached after about $80 \mathrm{~h}$ (Fig. 1). Termination of growth coincided with the exhaustion of glucose from the medium. Astaxanthin was found to be the major xanthophyll in all samples of yeast taken during the fermentation and was produced mainly during the exponential growth period. Its production slowed soon after cessation of growth. The concentration of xanthophylls in the cells increased from 92 to $225 \mu \mathrm{g} \mathrm{g}^{-1}$ during the period of exponential growth $(30$ to $40 \mathrm{~h}$ ) and then increased only slightly to about $260 \mu \mathrm{g}$ $\mathrm{g}^{-1}$ in the next 20 to $30 \mathrm{~h}$. On exhaustion of glucose, the concentration of xanthophylls increased steadily until $128 \mathrm{~h}$ when a final concentration of $406 \mu \mathrm{g} \mathrm{g}^{-1}$ was obtained. In contrast, the concentration of carotenes in $P$. rhodozyma during the lag and exponential phase was fairly constant at $6 \mu \mathrm{g} \mathrm{g}^{-1}$ and decreased to $3 \mu \mathrm{g} \mathrm{g}^{-1}$ in the stationary phase. The primary carotene identified in all samples during growth was $\beta$-carotene.

\section{Effect of $\mathrm{pH}$ on growth and pigment formation}

In a preliminary screening of buffers, it was found that $0 \cdot 1 \mathrm{M}$-potassium hydrogen phthalate and $0 \cdot 1 \mathrm{M}$-sodium phosphate buffered well over the necessary range of $\mathrm{pH}$ values and allowed good growth and pigmentation of $P$. rhodozyma. Citrate buffer was unsatisfactory because it inhibited growth. Lactate buffer was also unsuitable because a rise in $\mathrm{pH}$ of the culture broth occurred late in the exponential phase of growth, probably due to the utilization of lactate by P. rhodozyma (Miller et al., 1976).

In phthalate or phosphate buffer, the final yield of yeast was only slightly affected by $\mathrm{pH}$ in the range 3.8 to 7.5 (Fig. 2) in shake flasks. The growth rate of $P$. rhodozyma was much more affected by $\mathrm{pH}$ and was highest at $\mathrm{pH} 5 \cdot 8$. The yield of astaxanthin was also affected by medium $\mathrm{pH}$; a maximum yield of $2.0 \mu \mathrm{g} \mathrm{ml}^{-1}$ was obtained at $\mathrm{pH} 5.0$ and at this $\mathrm{pH}$ the concentration of astaxanthin in $P$. rhodozyma was also highest [510 $\mu \mathrm{g}$ (g yeast) ${ }^{-1}$ ]. Gener- 


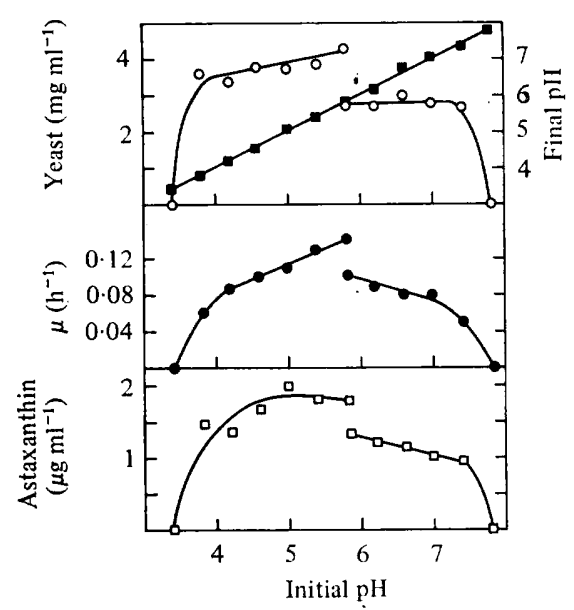

Fig. 2. Effect of pH on carotenoid formation and growth of $\boldsymbol{P}$. rhodozyma in shake flasks buffered with $0.1 \mathrm{~m}$-potassium hydrogen phthalate or $0.1 \mathrm{M}$-sodium phosphate (pH 5.8 to $7 \cdot 8$ ). Final yeast yield $(O)$, yeast growth rate $(O)$, astaxanthin yield $(\square)$ and final $\mathrm{pH}(\boldsymbol{G})$.

Table. 1. Effect of $p H$ on growth and astaxanthin formation of $P$. rhodozyma in fermenter

$\begin{array}{cccccc}\begin{array}{c}\mathrm{pH} \text { of } \\ \text { medium }\end{array} & \begin{array}{c}\text { Yeast } \\ \text { yield } \\ \left(\mathrm{mg} \mathrm{ml}^{-1}\right)\end{array} & \begin{array}{c}\text { Growth } \\ \text { rate, } \\ \mu\left(\mathrm{h}^{-1}\right)\end{array} & \begin{array}{c}\text { Astaxanthin } \\ {\left[\mu \mathrm{g}(\mathrm{g} \text { yeast })^{-1}\right]}\end{array} & \begin{array}{c}\text { Total } \\ \text { xanthophylls } \\ {\left[\mu \mathrm{g}(\mathrm{g} \text { yeast })^{-1}\right]}\end{array} & \begin{array}{c}\text { Total } \\ \text { carotenes } \\ {\left[\mu \mathrm{g}(\mathrm{g} \text { yeast })^{-1}\right]}\end{array} \\ 6.5 & 6.03 & 0 \cdot 14 & 325 & 332 & 11.0 \\ 5.5 & 9.68 & 0.12 & 336 & 339 & 15 \cdot 0 \\ 4.5 & 11.79 & 0.16 & 387 & 385 & 6.5 \\ 3.5 & 5.96 & 0.09 & 212 & 219 & 15.0\end{array}$

ally within the $\mathrm{pH}$ range $4 \cdot 0$ to $7 \cdot 0$ the choice of buffer (potassium hydrogen phthalate or sodium phosphate) had a greater effect on the parameters tested than did $\mathrm{pH}$. Sodium phosphate buffer was slightly inhibitory and the yield of yeast, yeast growth rate and astaxanthin formation were all lower in phosphate buffer than in phthalate buffer at the same $\mathrm{pH}(5 \cdot 8)$.

The influence of $\mathrm{pH}$ on carotenoid production was also studied in fermenters since the $\mathrm{pH}$ could be controlled by automatic titration so that the effects of buffers were eliminated. Of the four $\mathrm{pH}$ values studied (Table 1), the optimum was found to be $\mathrm{pH} 4.5$ where the maximum yield of cells, the highest growth rate and the maximum production of astaxanthin were obtained. Analysis of the pigments showed that astaxanthin was the dominant xanthophyll present at each $\mathrm{pH}$ value. However, the absorption spectrum of the carotene fraction from yeast grown at $\mathrm{pH} 3.5$ was strikingly different from that obtained at other $\mathrm{pH}$ values (Fig. 3). The primary carotene present at $\mathrm{pH} 3.5$ was $\beta$-zeacarotene whereas $\beta$-carotene dominated in yeast grown at the other $\mathrm{pH}$ values (see Table 2). After purification, these pigments were conclusively identified by their absorption spectra, chromatographic characteristics and mass spectra. $\beta$-Zeacarotene could not be found in cells grown at pH 4.5.

\section{Influence of temperature on growth and pigmentation of $P$. rhodozyma cultured in shake flasks}

The final yield of yeast was relatively constant at growth temperatures of $22^{\circ} \mathrm{C}$ and below, but the yield decreased considerably at temperatures above $22{ }^{\circ} \mathrm{C}$, the optimum for growth rate (Fig. 4). The highest temperature at which growth was observed was $27.5^{\circ} \mathrm{C}$; at this temperature $P$. rhodozyma increased its mass about twofold after inoculation and 


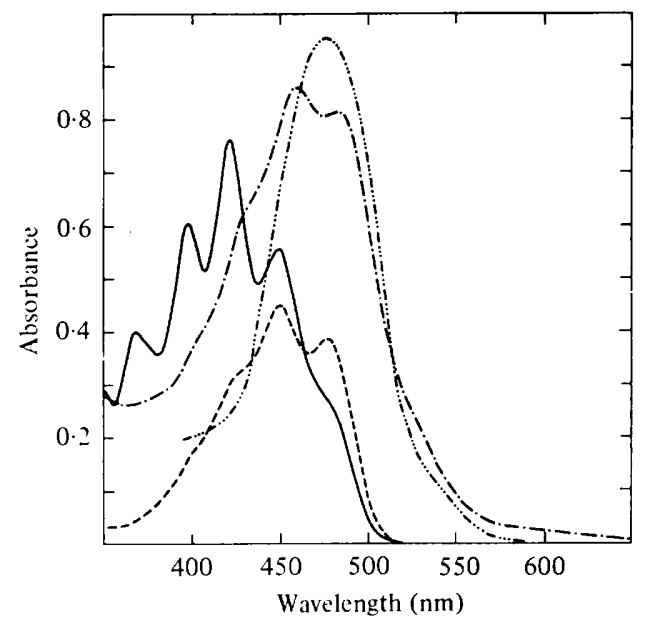

Fig. 3. Visible absorption spectra (in acetone) of the carotenes isolated from $P$. rhodozyma grown at pH 3.5 (- - ) and $\mathrm{pH} 4.5$ (- - - ) and of the total carotenoid extract of cells grown under aerobic $(\cdots-\cdots-)$ or microaerophilic $(-\cdot-\cdot)$ conditions.

Table 2. Analysis of carotenes isolated from $P$. rhodozyma grown in a fermenter at $\mathrm{pH} 3.5$ or 4.5

\begin{tabular}{|c|c|c|c|}
\hline \multicolumn{2}{|c|}{ pH 4.5} & \multicolumn{2}{|c|}{$\mathrm{pH} 3.5$} \\
\hline $\begin{array}{c}\mu \mathrm{g} \\
\text { isolated }\end{array}$ & $\begin{array}{c}\% \text { of } \\
\text { total }\end{array}$ & $\begin{array}{c}\mu \mathrm{g} \\
\text { isolated }\end{array}$ & $\begin{array}{l}\% \text { of } \\
\text { total* }\end{array}$ \\
\hline 27 & $77 \cdot 0$ & trace & $\sim 1$ \\
\hline 0 & 0 & 40 & 90 \\
\hline $2 \cdot 7$ & $7 \cdot 7$ & 1.5 & 3.0 \\
\hline 1.7 & $5 \cdot 0$ & 2.5 & 5.0 \\
\hline $3 \cdot 5$ & $10 \cdot 0$ & trace & $\sim 1$ \\
\hline
\end{tabular}

Carotene

$\beta$-Carotene $\beta$-Zeacarotene $\gamma$-Carotene Neurosporene Lycopene
Structure

$\beta, \beta$-Carotene

$7^{\prime}, 8^{\prime}$-Dihydro- $\beta, \psi$-carotene

$\beta, \gamma$-Carotene

7,8-Dihydro- $\gamma, \gamma$-carotene

$\gamma, \gamma$-Carotene

* Total yield of carotenes: $\mathrm{pH} 3 \cdot 5,15 \mu \mathrm{g}$ (g yeast) $)^{-1}$; $\mathrm{pH} 4 \cdot 5,7 \mu \mathrm{g}$ (g yeast) ${ }^{-1}$. The concentrations of xanthophylls were 219 and $385 \mu \mathrm{g}$ (g yeast) ${ }^{-1}$, respectively.

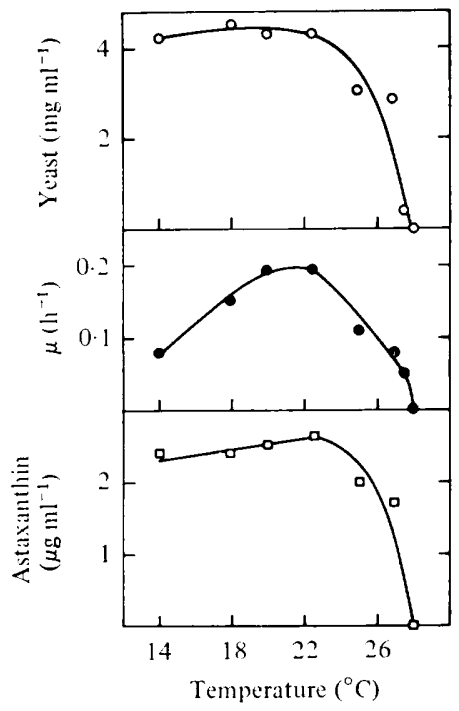

Fig. 4. Effect of temperature on growth and pigmentation of $P$. rhodozyma grown in shake flasks. Symbols as in Fig. 2. 
Table 3. Effect of carbon source on growth and pigmentation of $P$. rhodozyma in shake flask culture

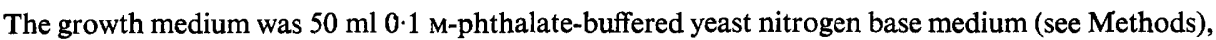
containing $0.6 \%$ (w/v) Bacto-peptone and $200 \mathrm{mg}$ carbon (supplied as the various sugars). The values represent the mean of two determinations. Carbon sources were sterilized separately from the basal medium. No growth occurred in the basal medium without the addition of a carbon source.

$\begin{array}{lccccc}\text { Carbon source } & \begin{array}{c}\text { Growth } \\ \text { rate, } \mu \\ \left(\mathrm{h}^{-1}\right)\end{array} & \begin{array}{c}\text { Yeast } \\ \text { yield } \\ \left(\mathrm{mg} \mathrm{ml}^{-1}\right)\end{array} & \begin{array}{c}\text { Yeast yield } \\ {\left[\mathrm{mg}(\mathrm{mg} \mathrm{carbon})^{-1}\right]^{*}}\end{array} & \begin{array}{c}\text { Astaxanthin } \\ \text { yield } \\ \left(\mu \mathrm{g} \mathrm{m}^{-1}\right)\end{array} & \begin{array}{c}\text { Astaxanthin } \\ \text { yield } \\ {\left[\mu \mathrm{g}(\mathrm{g} \text { yeast })^{-1}\right]}\end{array} \\ \text { D-Maltose } & 0 \cdot 14 & 3.63 & 0.91 & 1.86 & 512 \\ \text { D-Cellobiose } & 0.10 & 3.48 & 0.87 & 2.27 & 652 \\ \text { Sucrose } & 0.19 & 3.72 & 0.93 & 1.89 & 508 \\ \text { Succinate } & 0.09 & 2.66 & 0.67 & 1.33 & 500 \\ \text { D-Mannitol } & 0.16 & 3.68 & 0.92 & 1.80 & 489 \\ \text { D-Xylose } & 0.04 & 1.21 & 0.30 & 0.58 & 379 \\ \text { L-Arabinose } & 0.06 & 3.30 & 0.83 & 1.25 & 541 \\ \text { Glucono- } \delta \text {-lactone } & 0.10 & 1.48 & 0.37 & 0.80 & 421 \\ \text { D-Glucose } & 0.2 \mathrm{C} & 3.85 & 0.96 & 1.62 & 171 \\ \text { D-Glucose } \dagger & 0.21 & 6.46 & 0.81 & 1.11 & \end{array}$

* Assuming all carbon utilized. $+800 \mathrm{mg}$ carbon $[4 \%(\mathrm{w} / \mathrm{v})$ glucose $]$.

then stopped growing. The astaxanthin concentration in yeast grown at all the temperatures tested was constant (about $480 \mu \mathrm{g} \mathrm{g}^{-1}$ ). Insufficient yeast was obtained at $27.5^{\circ} \mathrm{C}$ to estimate the concentration of astaxanthin, but the cells were very pale. All the acetone extracts gave visible absorption spectra typical of astaxanthin. The concentrations of carotenes in the yeast also remained constant at about $7 \mu \mathrm{g} \mathrm{g}^{-1}$.

\section{Growth and pigmentation of $P$. rhodozyma grown on various carbon sources}

Cellobiose supported more pigmentation of $P$. rhodozyma $\left[652 \mu \mathrm{g}\right.$ (g yeast) $\left.{ }^{-1}\right]$ than any of the other carbon sources tested (Table 3). The other disaccharides, maltose and sucrose, also promoted high pigmentation. Sucrose and glucose promoted more rapid growth of $P$. rhodozyma $\left(\mu 0 \cdot 19 \mathrm{~h}^{-1}\right)$ than the other carbon sources. Although succinate and glucono$\delta$-lactone supported slow growth and rather sparse yields of yeast, these compounds promoted high concentrations of astaxanthin in P. rhodozyma. The sugar alcohol D-mannitol supported good yeast growth and pigmentation. The pentoses L-arabinose and D-xylose were utilized but resulted in slow growth and carotenoid production. D-Glucose supported a high rate of growth but only a moderate yield of astaxanthin, especially when present at a higher concentration $(4 \%, \mathrm{w} / \mathrm{v})$.

Influence of glucose concentration and shaking on growth and pigmentation of $P$. rhodozyma

As $P$. rhodozyma is a fermentative yeast, growth and pigment production were studied in a wide range of glucose concentrations in YM medium in shake flasks. The final yield of yeast per $\mathrm{g}$ glucose utilized decreased significantly with increasing glucose concentrations in shake flasks. The yield of astaxanthin per $\mathrm{g}$ yeast followed a remarkably similar pattern (Fig. 5). However, because the total yield of yeast increased substantially in the high glucose media, more astaxanthin $\left(\mu \mathrm{g} \mathrm{ml}^{-1}\right)$ was produced. At concentrations of glucose above $10 \mathrm{mg} \mathrm{ml}^{-1}$, the efficiency of biomass and astaxanthin production decreased steadily. Above about $40 \mathrm{mg}$ glucose $\mathrm{ml}^{-1}$, the yeast yield per $\mathrm{g}$ glucose and astaxanthin yield per $\mathrm{g}$ yeast were less affected by increasing glucose concentrations than below $40 \mathrm{mg} \mathrm{ml}^{-1}$ (Fig. 5).

The production of carotenoids was also studied in a fermenter in medium containing $5 \%$ glucose (Fig. 6). Glucose was not completely utilized after $126 \mathrm{~h}$ in this medium; yeast yields were reduced to about half those obtained in the $1.5 \%$ glucose fermentation and the concentration of astaxanthin in $P$. rhodozyma decreased to $350 \mu \mathrm{g}$ (g yeast) ${ }^{-1}$ (compare 


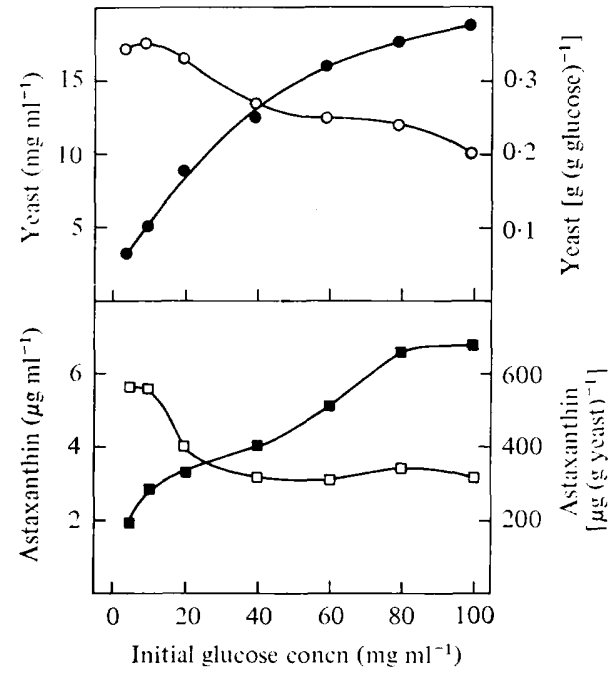

Fig. 5. Effect of glucose concentration on growth and pigmentation of $P$. rhodozyma. Final yeast yield $(\bigcirc)$, yeast yield per $\mathrm{g}$ glucose $(O)$, astaxanthin yield $(\square)$ and astaxanthin yield per $\mathrm{g}$ yeast $(\square)$. Calculations corrected for residual glucose. The growth medium contained (per litre in $0 \cdot 1 \mathrm{M}$-phthalate buffer, $\mathrm{pH} 5 \cdot 0$ ): $3 \mathrm{~g}$ yeast extract, $3 \mathrm{~g}$ malt extract, $6 \mathrm{~g}$ peptone (YM basal broth) and various concentrations of D-glucose.

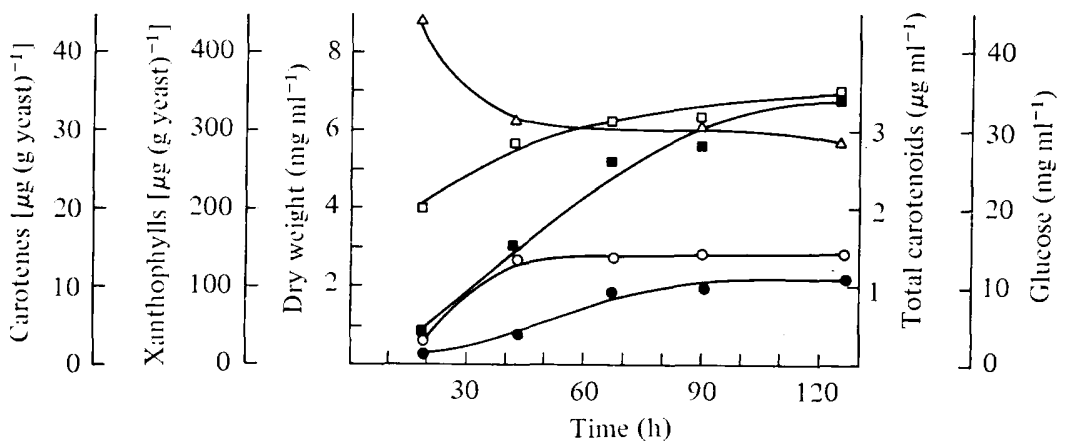

Fig. 6. Effect of $5 \%$ glucose on carotenoid formation and growth of $\boldsymbol{P}$. rhodozyma in fermenter batch culture. Yeast growth $(\bigcirc)$, total carotenoid formation (O), xanthophyll (astaxanthin) formation $(\square)$, carotene synthesis $(\square)$ and glucose utilization $(\triangle)$.

Fig. 1). However, the concentrations of total carotenoid pigment in the cells grown at the two glucose concentrations were almost the same (about $400 \mu \mathrm{g} \mathrm{g}^{-1}$ ); this was because the concentration of carotenes was 12-fold higher in the cells grown in the high-glucose medium. The primary carotene present in yeast grown in the $5 \%$ glucose medium, from all fermenter samples, was $\beta$-carotene. In addition, approximately $2 \cdot 5 \%$ of the total carotenes in the cells was found to be $\beta$-zeacarotene. The absorption spectrum of the xanthophyll fraction, in all samples, was identical to that of astaxanthin and therefore we did not analyse this group of pigments for concentrations of individual carotenoids.

\section{Effects of relative aeration on growth and pigmentation}

To study the effects of aeration on growth and carotenoid production in $P$. rhodozyma, we varied the volume of medium in the shake flasks between 25 and $200 \mathrm{ml}$ and their shaking rates from 50 to 200 rev. $\mathrm{min}^{-1}$ to produce a range of aeration rates. The dissolution rates of oxygen into a sulphite-containing solution indicated that a wide range of aeration rates was achieved (from 3.6 to $108 \mathrm{mmol} \mathrm{O}_{2}$ dissolved $\mathrm{1}^{-1} \mathrm{~h}^{-1}$ ). 


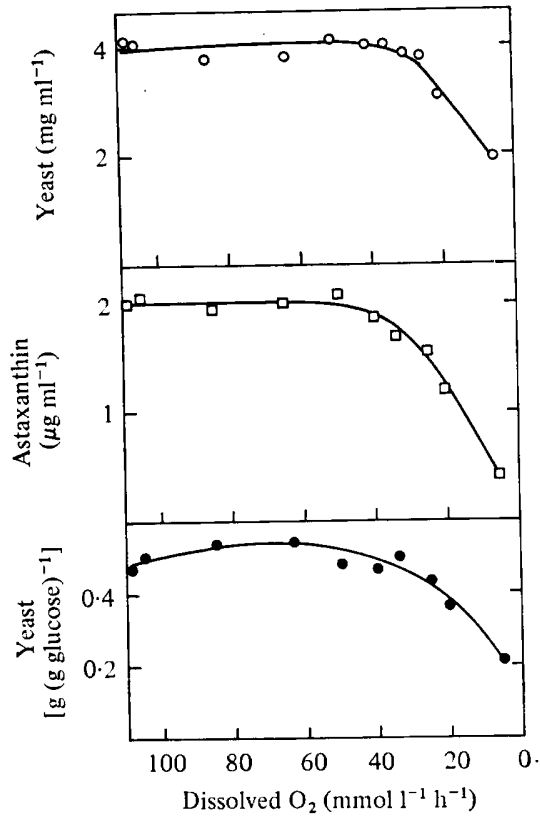

Fig. 7. Effect of aeration on carotenoid formation and growth of $P$. rhodozyma. Final yeast yield $(O)$, yeast yield per g glucose $(\bullet)$ and astaxanthin production $(\square)$. The abscissa represents the air supply as mmol $\mathrm{O}_{2}$ supplied $\mathrm{l}^{-1} \mathrm{~h}^{-1}$, obtained in 0.51 baffled shake flasks by using different medium volumes $(25,50,100$ and $200 \mathrm{ml})$ and shaking speeds $\left(5 \mathrm{C}, 100,150,200 \mathrm{rev} \cdot \mathrm{min}^{-1}\right)$.

Table 4. Carotenoids of $P$. rhodozyma grown under microaerophilic or aerobic conditions

Individual carotenoids isolated from cells $(\%$ of total carotenoid present)*

Carotenoid

Astaxanthin

Phoenicoxanthin

3-Hydroxy-3', 4'-didehydro-

$\beta, \psi$-caroten-7-one

3-Hydroxyechinenone

Echinenone

$\beta$-Carotene

Other carotenes
Structure

3,3'-Dihydroxy- $\beta, \beta$-carotene-4,4'-dione

3 -Hydroxy- $\beta, \beta$-carotene-4,4'-dione

3-Hydroxy- $\beta, \beta$-carotene-4-one

$\beta, \beta$-Carotene-4-one

$\beta, \beta$-Carotene

\begin{tabular}{|c|c|}
\hline \multicolumn{2}{|c|}{ present)* } \\
\hline $\begin{array}{l}\text { Microaero- } \\
\text { philic }\end{array}$ & Aerobic \\
\hline $\begin{array}{r}26 \\
4\end{array}$ & $\begin{array}{r}87 \\
6\end{array}$ \\
\hline 9 & $<1$ \\
\hline$<1$ & 2 \\
\hline $\begin{array}{l}27 \\
33\end{array}$ & $\begin{array}{l}3 \\
2\end{array}$ \\
\hline$<1$ & $<1$ \\
\hline
\end{tabular}

* Total carotenoid yield: aerobic, $509 \mu \mathrm{g}$ (g yeast) $)^{-1}$; microaerophilic, $244 \mu \mathrm{g}$ (g yeast) ${ }^{-1}$.

The yields of cell mass and astaxanthin were fairly independent of oxygen dissolution rates except at the lowest aeration values, i.e. less than $30 \mathrm{mmol} \mathrm{O}_{2} \mathrm{l}^{-1} \mathrm{~h}^{-1}$ (Fig. 7). Below this level, the yields of yeast and astaxanthin were significantly reduced; at the lowest oxygen dissolution rate $\left(3.6 \mathrm{mmol} \mathrm{l}^{-1} \mathrm{~h}^{-1}\right)$ the yield of yeast decreased from the usual value of about $4.0 \mathrm{mg} \mathrm{ml}^{-1}$ to $2.0 \mathrm{mg} \mathrm{ml}^{-1}$ and the yield of astaxanthin decreased from approximately $2 \cdot 0$ to $0 \cdot 3 \mu \mathrm{g} \mathrm{ml}^{-1}$.

Because low aeration drastically influenced the concentration of carotenoids in $P$. rhodozyma, we incubated $P$. rhodozyma without an air supply in the fermenter. Under these conditions, the yeast tripled its biomass but then grew no more. Addition of ergosterol and Tween 80 to the medium did not promote growth. The harvested yeast was low in total 
carotenoids ( $244 \mu \mathrm{g} \mathrm{g}^{-1}$ ) and the visible absorption spectrum of the total carotenoid extract was not typical of astaxanthin (see Fig. 3). The concentration of xanthophylls was $163 \mu \mathrm{g}$ $\mathrm{g}^{-1}$ and of carotenes $81 \mu \mathrm{g} \mathrm{g}^{-1}$. The concentrations of individual carotenoids are given in Table 4. Under these microaerophilic conditions, comparatively little astaxanthin was produced; it made up only $26 \%$ of the carotenoid mixture compared with nearly $90 \%$ under aerobic growth conditions. The primary carotenoid synthesized under anaerobic conditions was $\beta$-carotene. Echinenone was also produced in much higher amounts anaerobically than in aerobically grown yeast.

Because low aeration and high glucose in the growth medium caused significant reductions in the efficiency of astaxanthin production, we decided to combine these effects. In a medium containing $4 \%(\mathrm{w} / \mathrm{v})$ glucose and with $\mathrm{O}_{2}$ supplied at $5.0 \mathrm{mmol} \mathrm{l}^{-1} \mathrm{~h}^{-1}$, the specific growth rate of $P$. rhodozyma was $0.1 \mathrm{~h}^{-1}$ and the yield of yeast was only $0.05 \mathrm{mg}$ (g glucose) ${ }^{-1}$. The cells were tan rather than pink and contained only $30 \mu \mathrm{g}$ total carotenoid $\mathrm{g}^{-1}$. On analysis the total pigment extract showed a visible absorption spectrum similar to $\beta$-zeacarotene. Chromatography showed that the yeast contained little astaxanthin but proportionately higher concentrations of less polar pigments (probably carotenes) including $\beta$-zeacarotene.

\section{Light and carotenoid production}

Phaffia rhodozyma was grown in triplicate shake flasks in YM medium in the dark or with high light intensity $(2700 \mathrm{~lx})$. The yield of yeast in the dark- and light-grown cultures was 3.7 and $3.5 \mathrm{mg} \mathrm{ml}^{-1}$, respectively. Observation of the shake flasks after growth suggested that the light-grown cultures synthesized more astaxanthin, because the cells had a redder hue. This may have been due to different relative concentrations of the carotenoids present, since the assay of astaxanthin gave only a slightly increased mean, $538 \mu \mathrm{g} \mathrm{g}^{-1}$ compared to $510 \mu \mathrm{g} \mathrm{g}^{-1}$ for the dark-grown culture.

\section{Effect of nitrogen source and complex media on pigmentation in $P$. rhodozyma}

The concentration of ammonium sulphate in the range 0.25 to5 $\mathrm{mg} \mathrm{ml}^{-1}$ had little effect on the yeast growth rate, final yeast biomass or on carotenoid production in YNB medium supplemented with $1 \%$ D-glucose. The substitution of $\left(\mathrm{NH}_{4}\right)_{2} \mathrm{HPO}_{4}$ or peptone for $\left(\mathrm{NH}_{4}\right)_{2}{ }_{2}$ $\mathrm{SO}_{4}$ at various concentrations also did not affect these values. However, when increasing concentrations of yeast extract $\left(0 \cdot 1\right.$ to $\left.10 \mathrm{mg} \mathrm{ml}^{-1}\right)$ were added to a vitamin-free medium (vitamin-free yeast base, Difco), there was an increase in pigmentation from 156 to $524 \mu \mathrm{g}$ $\mathrm{g}^{-1}$. Similarly, when $P$. rhodozyma was grown in fermenter culture on complex media - (i) brewer's malt wort diluted to a specific gravity of 1.020 or (ii) addition of 1.01 of colourless tomato pressings to 2.01 of the standard medium - the carotenoid yields were 712 and $814 \mu \mathrm{g}$ $\mathrm{g}^{-1}$, respectively, after $60 \mathrm{~h}$ growth.

\section{DISCUSSION}

Astaxanthin formation in $P$. rhodozyma is clearly growth-associated, although its production does not exactly coincide with increase in biomass. The growth-associated production of astaxanthin contrasts with results found with Sporobolomyces roseus (Bobkova, 1965) and Rhodotorula glutinis (Vecher \& Kulikova, 1968), where carotenoid production occurred only after yeast growth had stopped; it is also common in the Phycomycetes (e.g. Phycomyces blakesleeanus) for the primary period of carotenoid synthesis to follow cessation of growth.

Phaffia rhodozyma is the only carotenogenic yeast that ferments glucose (Miller et al., 1976). It would be expected that growth at low dissolved oxygen concentrations and/or high glucose levels would promote fermentative metabolism and possibly affect carotenoid production. When the supply of oxygen to $P$. rhodozyma was reduced to low levels there 
was a decrease in the yield of yeast per g glucose utilized, which suggested that $P$. rhodozyma was fermenting. This was accompanied by a decrease in astaxanthin concentration and an accumulation of $\beta$-carotene. Similarly, when $P$. rhodozyma was cultured with increasing concentrations of glucose, fermentative growth was indicated by decreased yields of yeast per $\mathrm{g}$ carbo.1 utilized and this was accompanied by decreases in astaxanthin concentration. These results show that astaxanthin production is inhibited under fermentative conditions. This is supported by the fact that glucose, which is readily fermented by $P$. rhodozyma, promoted relatively low levels of astaxanthin production. Cellobiose, however, which can only be used aerobically by $P$. rhodozyma (Phaff et al., 1972), stimulated relatively high astaxanthin production as did succinate, which may be directly utilized aerobically by the tricarboxylic acid cycle.

Changes in the lipid content of aerobically and anaerobically grown Saccharomyces cerevisiae have been interpreted as a reflection of the state of mitochondrial development (Jakovicic et al., 1971). The inability to form ergosterol in mutants of $S$. cerevisiae (Bard et al., 1974) is due to lesions in the biosynthesis of porphyrins rather than direct lesions in the synthesis of sterols, which implies the requirement of an active respiratory chain for the synthesis of ergosterol. It is possible that an active respiratory chain is also needed in the biosynthesis of carotenoids, since these share many enzymic steps with sterols in their formation from acetyl-CoA. Exposure of anaerobically grown cells to oxygen causes a rapid induction of the sterol-synthesizing enzyme, 3-hydroxy-3-methyl-glutaryl CoA reductase (Berndt et al., 1973). Further, since carotenoids have been reported to be located primarily in the mitochondria in certain fungi (Heim, 1946), this location may also indicate their site of synthesis.

Very little is known about the formation of xanthophylls in micro-organisms. It is generally assumed that hydroxyl functions at C-3 and C-3' of the carotenoid skeleton arise from the incorporation of molecular oxygen by carotene hydrocarbons. The evidence for this hypothesis is indirect (see Britton, 1976). Nothing is known about the introduction of oxygen functions at C-4 and C-4' except that it is likely that oxo groups are formed through the hydroxy intermediates (Britton, 1976). When $P$. rhodozyma was cultured with minimal oxygen supply, the astaxanthin yields were greatly reduced, and the yeast tended to accumulate $\beta$-carotene as well as the monoketone echinenone. These results suggest that the hydroxyl functions in astaxanthin are formed only in the presence of oxygen and that carotenes and echinenone are formed under conditions of low aeration. When we aerated anaerobically grown stationary phase cells, there was no detectable change in their astaxanthin content.

$\beta$-Zeacarotene accumulated in cells of $P$. rhodozyma grown under adverse environmental conditions. This pigment was not originally detected in the analysis of the pigments of $P$. rhodozyma by Andrewes et al. (1976). Its isolation suggests that the well known alternative route for $\beta$-carotene synthesis is operative in $P$. rhodozyma thus:

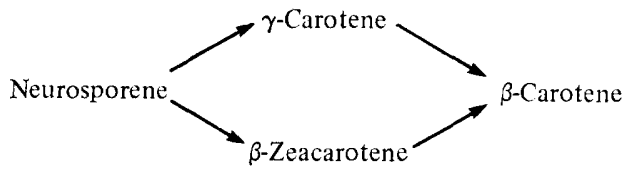

$\beta$-Zeacarotene accumulates in cells of Rhodotorula (Simpson et al., 1964) and Phycomyces blakesleeanus in the presence of inhibitors. Because $\beta$-zeacarotene usually accumulates in cells only under adverse conditions, e.g. in the presence of inhibitors such as diphenylamine or in stressful environments, it may be regarded as an indicator of inefficient carotenoid biosynthesis. Its formation can perhaps be rationalized by a hypothesis of Goodwin and his coworkers, (McDermott et al., 1974) who postulate that the synthesis of zeaxanthin by Flavobacterium spp. involves an enzyme complex with two active sites, each of which acts on a carotenoid 'half molecule' in synchrony and with equal efficiency, i.e. 
desaturation or cyclization of each half molecule proceeds at the same rate. Under abnormal conditions, however, the individual sites may not act in synchrony and asymmetrical products such as $\beta$-zeacarotene may result. Further, genetic evidence has shown that there is an enzyme complex with two cyclases for the formation of $\beta$-carotene in Phycomyces (De la Guardia et al., 1971).

In contrast to many other micro-organisms, light does not stimulate carotenogenesis in $P$. rhodozyma. The biosynthesis of astaxanthin was, however, greatly enhanced by growth in the presence of tomato wastes. The high yield of carotenoid obtained with the tomato supplement suggests that carotenoid precursors may enter the cell and enhance carotenoid production. These results indicate the possibility of commercial production of astaxanthin by $P$. rhodozyma using citrus or vegetable wastes as adjuncts in the fermentation.

This research was financially supported by Sea Grant no. NOAA-04-6-158 R/R-11. A traineeship was provided by Sea Grant for E. A. Johnson.

\section{REFERENCES}

Andrewes, A. G., Phaff, H. J. \& Starr, M. P. (1976). Carotenoids of Phaffia rhodozyma, a red pigmented fermenting yeast. Phytochemistry 15, 1003-1007.

Bae, M., LeE, T. H., Yokoyama, H., Eoetzer, H. G. \& ChICHester, C. O. (1971). The occurrence of plectaniaxanthin in Cryptococcus laurentii. Phytochemistry 10, 625-629.

Bard, M., Woods, R. A. \& Haslam, J. M. (1974). Porphyrin mutants of Saccharomyces cerevisiae: correlated lesions in sterol and fatty acid biosynthesis. Biochemical and Biophysical Research Communications 56, 324-330.

Berndt, J., Boll, M., Lowel, M. \& Gaumert, R. (1973). Regulation of sterol biosynthesis in yeastinduction of 3-hydroxy-3-methyl-glutoryl $\mathrm{CoA}$ reductase by glucose. Biochemical and Biophysical Research Communications 51, 843-848.

Bobkova, T.S. (1965). Carotenoid pigments of mycobacteria and yeasts. Mikrobiologiya (English translation) 34, 229-233.

Britton, G. (1976). Biosynthesis of carotenoids. In Chemistry and Biochemistry of Plant Pigments, vol. 1, pp. 262-327. Edited by T. W. Goodwin. New York: Academic Press.

Cooper, C. M., Fernstrom, G. A. \& Miller, S. A. (1944). Performance of agitated gas-liquid contractors. Industrial and Engineering Chemistry 36, 504-509.

Davies, B. H. (1976). Carotenoids. In Chemistry and Biochemistry of Plant Pigments, p. 116. Edited by T. W. Goodwin. New York: Academic Press.

De la Guardia, M. D., Aragon, C. M. G., Murillo, F. \& Cerda-Olmedo, E. (1971). A carotenogenic enzyme aggregate in Phycomyces: evidence from quantitative complementation. Proceedings of the National Academy of Sciences of the United States of America 68, 2051-2058.

Goodwin, T. W. (1972). Carotenoids in fungi and nonphotosynthetic bacteria. Progress in Industrial Microbiology, vol. 11, pp. 29-89. Edited by D. J. D. Hockenhull. Edinburgh: Churchill Livingstone.

Heim, P. (1946). Sur les pigments carotiniens des champignons. Comptes rendus des séances de l'Académie des sciences 223, 1170-1172.

Jakovicic, S., Getz, S., Rabinowitz, M., JAKob, H.
\& SwIFT, H. (1971). Cardiolipid content of wild type and mutant yeasts in relation to mitochondrial function and development. Journal of Cell Biology 48, 490-502.

Johnson, E. A., Conklin, D. E. \& Lewis, M. J. (1977). The yeast Phaffia rhodozyma as a dietary pigment source for salmonids and crustaceans. Journal of the Fisheries Research Board of Canada 34, 2417-2421.

Johnson, E. A., Villa, T. G., Lewis, M. J. \& Phaff, H. J. (1978). Simple method for the isolation of astaxanthin from the basidiomycetous yeast Phaffia rhodozyma. Applied and Environmental Microbiology 35, 1155-1159.

LiU, I. S., Lee, T. H., Yokoyama, H., Simpson, K. L. \& Chichester, C. O. (1973). Isolation and identification of 2-hydroxyplectaniaxanthin from Rhodotorula aurantiaca. Phytochemistry 12, 2953-2957.

McDermott, J. C. B., Brown, D. J., Britton, G. \& GoodwIN, T. W. (1974). Alternative pathways of zeaxanthin synthesis in a Flavobacterium species. Biochemical Journal 144, 231-243.

Miller, M. W., Yoneyama, M. \& Soneda M. (1976). Phaffia, a new yeast genus in the Deuteromyotina (Blastomycetes). International Journal of Systematic Bacteriology 26, 286-291.

Phaff, H. J., Miller, M. W., Yoneyama, M. \& SonedA, M. (1972). A comparative study of the yeast florae associated with trees on the Japanese lslands and on the west coast of North America. In Fermentation Technology Today, pp. 759-774. Edited by G. Terui. Osaka, Japan: Society of Fermentation Technology.

Simpson, K. L., Nakayama, T. O. M. \& Chichester, C. O. (1964). Biosynthesis of yeast carotenoids. Journal of Bacteriology 88, 1688-1694.

Simpson, K. L., Chichester, C. O. \& Phaff, H. J. (1971) Carotenoid pigments of yeast. In The Yeasts, vol. 2, pp. 493-515. Edited by A. H. Rose \& J. S. Harrison. New York: Academic Press.

Sumner, J. B. \& Somers, F. (1949). Laboratory experiments in Biological Chemistry. New York: Academic Press.

Vecher, A. S. \& Kulikova, A. (1968). Changes in polyene compounds at various stages of carotenoid development of Rhodotorula gracilis. Mikrobiologiya (English translation) 37, 558-560. 